\title{
The Strategic Environment of the US-Australia Alliance in the Indo-Pacific Era
}

\author{
Alexander L. Vuving
}

To be published as Chapter 2 in Scott D. McDonald and Andrew T.H. Tan, eds., The Future of the United States-Australia Alliance: Evolving Security Strategy in the Indo-Pacific (London: Routledge, 2021) 


\section{$\underline{\text { Abstract }}$}

The strategic environment is best likened to an ever-changing river that consists of a myriad of interacting currents residing at various depths and moving with different speeds. Shaping this environment effectively is not the same as causing changes or making differences, but is similar to swimming efficiently in this river. The most powerful currents in this river are related to climate, demographic, technological and economic changes, great power relations, big catastrophes, and human dynamics. The ongoing COVID-19 pandemic will have the largest impact on the strategic environment in the short to medium term. Although the directions of many changes brought about by the global plague are still unfathomable as the pandemic continues to unfold, four trends accelerated by the pandemic - the growth in importance of the cyber domain, the bifurcation of the world economy, the intensification of great power competition, and the transformation of international architecture - are constituting the shape of things to come. In the medium to long term, the hegemonic contest between China and the United States will have the largest impact on the strategic environment. Metaphorically speaking, it is creating the largest vortex in the river that is the strategic environment. East Asia and Australia will be drawn into this vortex even against the best effort to stay outside. This chapter argues that, contrary to the belief of many, there is no Thucydides Trap - the structural cause of war-in this hegemonic contest because it is structured as a game of chicken, not a prisoner's dilemma. It is important for any player in this environment to recognize the strategic structure of the US-PRC hegemonic contest and apply the best strategy for it as suggested by this structure. China has masterfully played the game of chicken with its gray zone tactics, its pursuit of "war by other means', i.e., its weaponization of the non-military, even of risks. The US-PRC hegemonic contest will not resemble the Cold War much beyond this strategic structure. It will be very different from the Cold War in important aspects, including the ideological and economic realm. Most strikingly, the main front lines of the contest will be in the maritime and cyber domains and, consequently, will be far more fluid and unstable than those of the Cold War. 


\section{Introduction}

As the US-Australia alliance connects a global power with a regional power, its ambit is global with a regional focus. This region was called the 'Asia-Pacific' in the decades extending from the last stage of the Cold War (the 1980s) to the last stage of the post-Cold War period (the 2010s). Australia was a strong proponent of the idea of the Asia-Pacific, a posture that manifested not least in Australia's driving role in the creation of the Asia-Pacific Economic Cooperation (APEC). During the 2010s, the idea of the Indo-Pacific emerged to replace that of the Asia-Pacific, and Australia is again a promoter of the new idea (Medcalf 2020). In both constructs, Australia retains its geographic position as one of the pivots of the region: a hinge country between Asia and the Pacific, and between the Indian and Pacific Oceans. Like the Asia-Pacific before it, the IndoPacific is both a region and an idea, a fact and a vision. If the Asia-Pacific anticipated a trough in great power competition and strived for an economically integrated and prosperous region, the Indo-Pacific is a response to the rise of great power competition with the vision of a region free of domination by any great power and open to all. ${ }^{1}$ Only partly fulfilled, the vision of the Asia-Pacific has already been overcome by the contestation of the Indo-Pacific, One Belt One Road, and possibly other visions to come. This incompleteness resulted from the changing strategic environment. The fate of the Indo-Pacific, One Belt One Road, and other visions will also hinge on the evolution of the strategic environment in the decades to come.

This chapter will examine the strategic environment of the US-Australia alliance in the Indo-Pacific era. It starts with a general framework that teases out the chief currents shaping the strategic environment. One of these currents is the ongoing COVID-19 pandemic with its tremendous destructive-and creative-forces. The second section will identify the trends triggered or accelerated by this pandemic that will have a large impact on the post-Covid world. Key questions about peace and war and about strategy will be given an analytic foundation in the third section. This section will discuss the strategic structure of great power competition while the

\footnotetext{
${ }^{1}$ Japan was the first to announce the vision of a free and open Indo-Pacific, an idea that was soon embraced and further developed by the United States. Australia and India, where the idea of the Indo-Pacific had circulated before it gained currency in the United States, followed suit and, in a "Shared Vision" issued in June 2020, endorsed a "free, open, inclusive and rules-based Indo-Pacific region." As a response to the US initiative and driven by Indonesia, another hinge country between the Indian and the Pacific Ocean, ASEAN adopted in 2019 an "Outlook on the Indo-Pacific" that emphasizes ASEAN centrality, openness, and inclusivity, among others.
} 
fourth section will address the implications of this structure for the strategies of the players and the outcomes of their game. It argues that, contrary to the belief of many, the Thucydides Trap, i.e., the structural cause of war, does not exist in all cases of hegemonic contest. If war is inevitable in some cases, peace is equally attainable in some others, depending on the strategic structure of the competition. Based on the previous sections, the fourth section will further characterize the strategic environment by comparing it with the last peak period of great power competition-the Cold War. As with the Cold War, there is no Thucydides Trap in the hegemonic contest between the United States and China. But the next "Cold War" will be very different from the last in important aspects, including the ideological and economic realm. Most strikingly, the main front lines of the contest will be in the maritime and cyber domains and, consequently, will be far more fluid and unstable than those of the Cold War.

\section{The Multi-Current River That Is the Strategic Environment}

The strategic environment is the totality of factors that affect the strategic trajectories of the actors concerned. These factors change at different paces, ranging from very rapid changes measurable in days and months to very slow changes that become visible only in several decades. One characteristic of the strategic environment is that it never stops changing. Its change results from a myriad of changes that occur at very different paces and the interaction of these multi-speed changes. These two characteristics make the strategic environment a multi-current river: it is interwoven and driven by multiple interacting currents residing at various depths and moving with different speeds. The currents that make up this river are numerous, but the most powerful ones can be grouped under six headings: climate change, demographic change, technological and economic change, great power relations, catastrophes of a large magnitude, and human dynamics in each society.

Climate change deeply shapes the strategic environment. Not all changes in the climate shape the strategic environment, and the ones that do often move very slowly; their effect on the big picture can only be felt in the very long term, in many decades. Many effects of climate change on the strategic environment have their harbinger in the melting of the ice cap in the Arctic and Antarctica. Between 1989 and 2019, the Arctic ice cap lost 2.69 million square kilometer, or 38.4 percent of its area, and is now declining with a rate of 12.85 percent per decade. The land ice sheets 
in Antarctica also lost mass an average of 147 gigatonnes per year between 2002 and 2020 (NASA n.d.). These trends are likely to continue in the next decades.

The melting of the Arctic icecap has opened a new transoceanic trading route- the Northeast Passage - that is the shortest sea route connecting Western Europe and Eastern Asia. The opening of the Northeast Passage has intensified power competition in the Arctic, drawing not just resident great powers Russia and the United States, but also China, a non-resident great power, into a 'great game' in the region.

The melting of ice at Antarctica makes it easier to exploit the natural resources under its soil as well as the location of its land. China has been the most active to grasp this opportunity. Its action is certainly driven by its hunger for natural resources, but it may also reflect the instinct of a master go player searching for strategic places and of someone who wants to impress the world with a special feat. Replicating the South China Sea plot, China can multiply, enlarge, and turn its scientific bases in Antarctica into hybrid bases in a few decades. As the shortest routes from China to Antarctica run through Australia's waters, China's interests in Antarctica has added more strategic importance to Australia on the chessboard—or more precisely, the go board—of great power competition. China's strategic interests in the Arctic and Antarctica also helps to redefine the US-Australia alliance as an alliance 'from the Arctic to the Antarctic'.

A major consequence of the melting of ice at the Arctic and Antarctica is the rise of sea level. Although the sea does not rise equally in all places and some coral reefs such as Tuvalu, the proverbial sinking nation, actually grew larger despite sea level rise, the narrative that small islands in the middle of the ocean are sinking remains powerful particularly among the nations of the South Pacific, which are mostly small islands with vast exclusive economic zones (EEZs) (Nield 2018). Playing on this narrative, China can offer to help with its superior land reclamation capabilities, demonstrated spectacularly in the South China Sea, in return for certain rights on some strategically located islands and privileges in the vast EEZs of the Pacific islands. Australia and the United States must not be surprised by such bargains and ready for solutions.

Demographic change is a vast category for migrations and changes in different demographic structures of the population related to age, education, ideological orientation, etc. These changes affect the vitality and coherence of nations, the balance of power among them, and the shape of the strategic environment in the long term. Japan, South Korea, and China are the 
most rapidly ageing nations in the Indo-Pacific, while Pakistan, India, and Indonesia continue to have a youth bulge for one or more decades (United Nations, Department of Economic and Social Affairs, Population Division 2019). Ageing societies are faced with problems of a shrinking workforce, while violent extremism challenges countries with a sizable unemployed young population, and people tend to migrate from youthful countries to ageing ones. Being immigrant nations, Australia and the United States stand to win if they let in hard-working and talented people and leave out those whose attitude or aptitude may cause problems for the society. In the long term, population growths in India, Pakistan, Indonesia, Australia, and the United States and population losses in Japan and China will shift the balance of power in the Indo-Pacific in favor of the former at the expense of the latter, provided that the former maintain their national coherence.

Technological and economic changes move in waves, and the most powerful wave that will shape the strategic environment in the decades to come is the Fourth Industrial Revolution. Started in the 1990s, this fourth wave of the Industrial Revolution is characterized by the high speed of change and the intensity of innovation in the fields of information and communication technology. New technologies like big data, artificial intelligence, blockchain, the Internet of Things, and autonomous vehicles/weapons are revolutionizing our lives and the world and bringing in revolutionary changes in society, economy, military, and governance. With their help, humanity will reach new heights in our capabilities to produce resources, connect people, organize people, and coerce each other.

Each wave of the Industrial Revolution makes a new domain available to human activities: the Second Industrial Revolution added the air domain to the land and maritime domains; the Third Industrial Revolution opened up the space domain; the Fourth Industrial Revolution created the cyber domain. Like the other non-land domains, the cyber domain is more of a global commons than a national territory. A virtual domain, the cyber domain cannot be militarized in the traditional sense because it cannot host the traditional military means, but it has already been weaponized and can carry non-traditional military means that may be developed in the future.

Great powers are the most powerful actors in the system and their relations, whether cooperative or competitive, have the strongest direct impact on the overall balance of power that shapes the strategic environment. Unlike most other actors, which are 'system-takers', great powers are 
'system-makers'. Prior to the nuclear age, an upswing phase in production and technological innovation was often accompanied by a hegemonic war (Goldstein 1988). The Fourth Industrial Revolution is bringing a production upturn in a cycle that returns only in several decades, and since the 2010s, great power competition has also been on the rise. The hegemonic contest of our time is between the United States and the People's Republic of China (PRC). Russia and Islamic fundamentalists are also major global challengers of the United States but they are not systemmakers like America and China.

The strategic competition between China and the United States is most intense in the IndoPacific, where both countries have a part or whole of their territory. The system-makers of this region include China, America, Japan, and, increasingly, India. The United States, Japan, and India are united in their determination to thwart China's bid for predominance. Most other states in the region are behaving like swing states - hedging between the two superpowers or taking a side temporarily. China is building an alliance system with Chinese characteristics through a complex web of guanxi - the reciprocity of favors and the primacy of relationships-and 'debt traps' created by its One Belt One Road program. The United States is recruiting allies by strengthening ties with its Cold War allies and nurturing strategic partnerships with emerging regional powers.

A catastrophe of a large magnitude can upset the strategic environment. We are experiencing such a catastrophe-the COVID-19 pandemic. But such catastrophes can come in many forms. About 75,000 years ago the Toba volcanic eruption caused a years-long winter in large parts of the world and may have had an immense impact on the evolution of humanity. The Third Industrial Revolution had added radioactive contamination to the list, and the Fourth Industrial Revolution, still unknown catastrophes in the Internet of Things and disasters caused by artificial intelligence and autonomous weapons. These 'black swan' events change the world enormously in directions we cannot predict while affecting the world and humanity unevenly.

Human dynamics in each society contribute many deep currents that make up the strategic environment. History has plenty of examples when a charismatic leader like Napoleon, a social movement like socialism, an appealing ideology like nationalism, a far reaching reform like that of Genghis Khan, or 'new kids on the block' like the Islamic fundamentalists transformed the strategic environment. These dynamics often are unknown unknowns to the contemporaries and change the world in unpredictable ways. 


\section{The Post-COVID World}

Like other catastrophes of a large magnitude, the COVID-19 pandemic will leave a gigantic scare on humanity. It will cause tremendous changes in the ways people live and the institutions they create, and it will force people to rethink their ideas and habits and adjust to the new normal. The post-COVID world will be different from the pre-COVID one in many aspects, most of which have yet to become visible. But six months after the first outbreak in Wuhan, some changes triggered or accelerated by the pandemic that will have a significant impact on the strategic environment are already discernible.

First, the cyber domain, already indispensable for human life and a critical domain of human activities, has gained more importance and will be more so in the future. The cyber domain has become a lifeline during the pandemic, carrying much of human communications and social activities - tens of millions of people depend on it when working from home or in lockdown. The Fourth Industrial Revolution, with its reliance on the Internet of Things and mobile networks, renders the cyber domain essential for economics, politics, and security. In some respects, it has become more important than the air and space domains because it carries information that everyone relies on.

Human communications and social activities are present in the form of data in the cyber domain. These data can be collected, controlled, and manipulated by those that provide the software, devices, physical networks, and virtual platforms for the communications and activities to take place. As it stands today, a small number of 'big tech' companies dominates the markets for these goods and services. Their access to data and devices and their control of networks and platforms make them critical actors in the geopolitical system. These 'new kids on the block' have the power to change the system, though the power to make the system still lies in the hands of great powers.

Second, the COVID-19 pandemic has laid bare the vulnerability and, in some cases, fatal dependency of many countries on China, urging some to diversify the supply chains and reduce their dependence on China. The United States, which boasts the world's largest economy, and Japan, which has the world's third largest, are leading effort to diversify their supply chains, even 
decouple their economy, from the world's second largest economy-China. As a part of its economic stimulus package to cushion the negative impact of the pandemic, Japan has earmarked \$2.2 billion to help its firms to shift production out of China (Bloomberg 2020). In late April 2020, alluding to a video conference initiated by the United States and including six other Indo-Pacific countries - Australia, India, Japan, South Korea, New Zealand, and Vietnam-which make up a new grouping called the 'Quad Plus' by observers, US Secretary of State Mike Pompeo said that Washington was working with these 'friends' to explore 'how we restructure these supply chains to prevent something like this from ever happening again' (Pompeo 2020a). In early May 2020, Reuters reported that 'the U.S. Commerce Department, State and other agencies are looking for ways to push companies to move both sourcing and manufacturing out of China'. According to a senior US official cited by the Reuters report, 'the United States is pushing to create an alliance of "trusted partners" dubbed the "Economic Prosperity Network", (Pamuk and Shalal 2020). These efforts are unlikely to achieve their objectives in the short term, and decoupling will not happen overnight, but with the intensification of power competition between China and its global, regional, and subregional rivals, the bifurcation of the world economy will be a long-term trend in the next decades.

Third, the COVID-19 pandemic presents a golden opportunity for hard and soft power competition between strategic rivals both at the global and the regional level. China and the United States have engaged in a blame game regarding who is responsible for causing and worsening the pandemic. The global preoccupation with the health crisis appeared to give China an opportunity to step up aggression on the conflict zones along its land and sea frontiers. In the South China Sea, China continued to be more assertive, a trend that started around 2007 and ratcheted up every two years or so since. Examples of PRC aggression during the first six months of the COVID-19 pandemic include the survey of a vast swath of waters within Malaysia's EEZ, the sinking of Vietnamese fishing boats, and large-scale military drills simulating island seizure (Asia Maritime Transparency Initiative 2020; Al Jazeera 2020; Japan Times 2020). The United States responded with rare actions that clearly sent a strong signal of US commitment to the region. US warships were seen in the scenes of 'cat and mouse' games between Chinese, Vietnamese, and Malaysian vessels. In July 2020, for the first time since 2014, two US aircraft carriers were present at the same time in the South China Sea; moreover, they conducted exercises when China also carried out military drills in the region (Trevithick 2020). In July, the United States for the first time 
explicitly rejected a large part ofChina's maritime and territorial claims in the south and east South China Sea (Pompeo 2020b). Also during the pandemic, although no shot was fired, a deadliest clash between China and India since their border war of 1962 broke out in the Ladakh section of their Line of Actual Control. Tellingly, Washington extended 'deepest condolences' to New Delhi and accused Beijing of escalating border tensions with India (PTI 2020; Basu 2020).

Fourth, the pandemic has strengthened the role of the nation-state and weakened that of the existing international organizations. The strongest and most effective responses to the pandemic came from the state, while most multilateral institutions receded into the sideline. As nation-states badly need the cooperation of others, it is unlikely that multilateral institutions will fade away in the post-COVID World. Rather, the pandemic will accelerate major changes in the international architecture, shaking up the foundations of many existing international organizations, throwing some into irrelevance, while facilitating the creation of new groupings and giving a new face to international architecture.

This transformation of the international architecture had already started well before the coronavirus ravaged humanity. International organizations work well if the great powers that sponsor them cooperate. But if their competition intensifies, international organizations will either become the arena of their competition or be weaponized by one against the other. As a result, these organizations will be paralyzed by the power rivalry, sometimes abandoned by a great power that has previously sponsored it. Great powers unsatisfied with existing multilateral institutions will create new ones under their leadership. This trend had started in the 2010s and will be even stronger in the 2020s.

The transformation of the international architecture will be most salient in the Indo-Pacific region, the core region of China's rise and the Australia-US alliance. The regional architecture of the Asia-Pacific era, dominated by APEC, the Asean Regional Forum (ARF), the East Asia Summit (EAS), and the Asean Defence Ministers' Meeting Plus (ADMM+), will be replaced by new architecture that better reflects the efforts of regional great powers and middle powers to realize their new visions and to cope with the changing strategic environment. The Association of the Southeast Asian Nations (ASEAN) will continue to work at the level of the lowest common denominator, which will be even lower in the future, as all members of the group need it in their coping with the vicissitude of great power relations. But given the growing diversity of their higher 
interests, ASEAN will be less united and Southeast Asia cannot avoid becoming a battlefield of the struggle for spheres of influence between the two opposing great power camps.

These trends - the growth in importance of the cyber domain, the bifurcation of the world economy, the intensification of great power competition, and the transformation of international

architecture - have already begun before the outbreak of the new coronavirus, but the pandemic is giving them strong impetus to accelerate. They are now integral parts of the contour of the postCOVID world, although the directions of many changes brought about by the global plague are still unfathomable as the pandemic continues to unfold.

\section{The Strategic Structure of Great Power Competition}

If the COVID-19 pandemic will have the largest impact on the strategic environment in the short to medium term, the US-PRC hegemonic contest will have the largest impact in the medium to long term. Although the future is open and everything is possible, not all possibilities are created equal. Some possibilities are more likely than others because the field of possibilities is shaped by structures. In particular, the strategic structure of a hegemonic contest ensures that some outcomes of the competition are more stable than others and some strategies of the contenders are more effective than others. Understanding the strategic structure of great power competition will help us answer key questions related to war and peace and strategy.

The inevitability of war is a structural feature of most cases of hegemonic contest in the past (Vuving 2020). Most great powers in the 5,200-year long history of great power competition saw their own predominance as the best option and their own subordination as the worst. For them, nothing, including war, was worse than subordination, because the subordinated was guaranteed to lose everything she valued most in life: honor, material wealth, independence, freedom. War with one or more peer challengers was their second worse option. Their second best option was a peaceful division of power that was acceptable to the great powers involved. We can symbolize this preference order as: $\mathrm{P}>\mathrm{D}>\mathrm{W}>\mathrm{S}$. When two great powers having this preference order engage in a strategic competition, they are locked in a situation that game theorists call 'prisoner's dilemma'. 
This situation has a distinctive structure that renders the best strategy for each player invariably to "defect"- to pursue its self-interest regardless of whether the opponent will cooperate or not. Hence the outcome of this game is inevitably the third best option for both players, which is confrontation. This outcome is evolutionarily stable and called a 'Nash equilibrium' after John Nash, who has shown mathematically how the structure of a strategic game dictates the best strategies for the players and thus determines the stable outcomes of their game. (Nash was awarded a Nobel Prize in economics 40 years later for this work.) In the language of game theory, the prisoner's dilemma has only one Nash equilibrium, and that is war when the players are great powers and their game is great power competition. The Greek historian Thucydides in his book, The History of the Peloponnesian War, left a famous comment on the inevitability of war between the hegemonic contenders of his time and place. He wrote, 'it was the rise of Athens and the fear that this inspired in Sparta that made war inevitable'. This was a $5^{\text {th }}$ century BC statement of the Nash equilibrium of the prisoner's dilemma.

Recently, Graham Allison invoked this quote and coined the term 'Thucydides's Trap' to describe the inclination to war of great power competition. He raised the specter of war between the United States and China and asked, 'Can America and China Escape Thucydides's Trap?' (Allison 2017). But the talk about the Thucydides Trap is misplaced at best because it is based on a fundamentally flawed assumption. It assumes that the Thucydides Trap exists whenever great powers engage in intense competition. This assumption ignores the fact that not all cases of great power competition share a similar structure as illustrated by Thucydides's quote about the inevitability of war between Athens and Sparta.

Indeed, some factors such as technology and geography can transform the prisoner's dilemma into a game of chicken (Vuving 2020). The two games are very different in terms of their outcomes and the best strategies for the players. How does technology transform the prisoner's dilemma into a game of chicken? Nuclear weapons, due to its 'overkill' effect, render war between nuclear-armed states worse than subordination. An all-out nuclear war between great powers can destroy all human life on Earth, first and foremost the lives of the great powers involved. How does geography transform the prisoner's dilemma into a game of chicken? Distance of the domain of contest from the home territory of a great power can make this contender perceive the value of predominance in that domain smaller than the cost of war in the home area. If leaders of great 
powers have this perception - that war is worse than subordination - then their preference order is $\mathrm{P}>\mathrm{D}>\mathrm{S}>\mathrm{W}$. When two great powers having this preference order engage in a strategic competition, they are locked in a situation that theorists call a 'game of chicken'.

The most striking difference between the prisoner's dilemma and the game of chicken is the reverse of their outcomes. If both players in the prisoner's dilemma are bound to clash, they are bound to avoid their clash in the game of chicken. Unlike the prisoner's dilemma, the game of chicken has three Nash equilibria (Colman 2017). Accordingly, the stable outcome of great power competition structured as a game of chicken can be either a division of power that both contenders more or less honor or the predominance of one of the contenders.

\section{Strategy and Outcome of Great Power Competition}

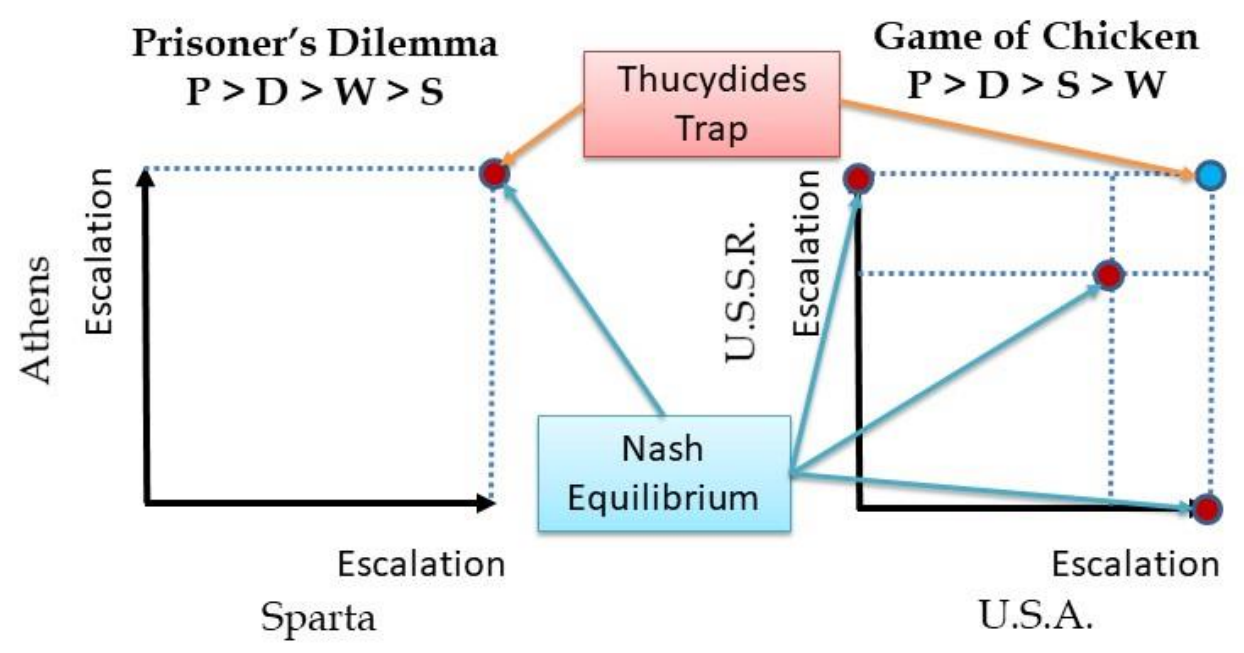

Figure 1. Strategy and Outcome of Great Power Competition.

Two of the major cases of great power competition in the past 500 years, the Cold War between the nuclear-armed United States and Soviet Union and the hegemonic contest between Portugal and Spain over colonial supremacy in the 'new world' of the late $15^{\text {th }}$ and early $16^{\text {th }}$ century, perfectly fit this model. Their results are well predicted by the Nash equilibria of the chicken game. The Cold War took the form of an extremely tense but relatively stable division of Europe, its central theater of contest, throughout the length of the conflict and eventually resulted 
in US hegemony when the Soviet Union imploded. The hegemonic contest between Spain and Portugal resulted in the 1494 Treaty of Tordesillas, which gave each contender the exclusive right to trade directly with and conquer a half of the globe. This agreement held well into the $16^{\text {th }}$ century even when it turned out that Spain had gotten the better end of the deal.

Two other cases in the 16 cases examined by Allison to advance the Thucydides Trap thesis also resulted in no war: the competition between the United Kingdom and the United States over naval supremacy in the Western Hemisphere in the late $19^{\text {th }}$ and early $20^{\text {th }}$ century and the competition between the UK and France on one side and Germany on the other over leadership in post-Cold War Europe. The US vs UK rivalry was an asymmetric game where for the UK, war was worse than subordination to the US in the Western Hemisphere (the UK preference order was $\mathrm{P}>\mathrm{D}>\mathrm{S}>\mathrm{W}$ ), while for the US, subordination to the UK was worse than war (the US preference order was $\mathrm{P}>\mathrm{D}>\mathrm{W}>\mathrm{S}$ ). In accordance with the Nash equilibrium of this game, the UK conceded to US naval supremacy in the Western Hemisphere rather than resort to war with the US. The UK/France vs Germany competition was structured as a game called 'concord' by game theorists. Their leaders and elites, especially those of Germany and France, have deeply learned the bloody lessons of World War II, World War I, and the many wars that ravaged Europe in the preceding centuries. This deep historical learning combined with the fear of a nuclear war has changed their preference order to $\mathrm{D}>\mathrm{P}>\mathrm{S}>\mathrm{W}$, rendering their great power competition a "concord," not a prisoner's dilemma or a game of chicken.

Yet, these 'peace' cases are treated as anomalies in the Thucydides Trap thesis, while the 'war' cases are regarded as normal (Allison 2017). ${ }^{2}$ In light of the strategic game structure, however, war was avoided in these cases because they did not share the structure of the rivalry between Athens and Sparta in the $5^{\text {th }}$ century BC or that between Britain and Germany in the early $20^{\text {th }}$ century, as Allison claims. In other words, there was no Thucydides Trap in the four cases that did not result in a war in the Thucydides Trap case file. The risks of war still exist in the games

\footnotetext{
${ }^{2}$ In his fullest statement of the Thucydides Trap thesis, Allison explained these anomalies by recourse to a plethora of ad hoc factors ranging from the Pope's authority, to economic, political, and security institutions, to the role of statesmen, timing, cultural commonalities, to nuclear weapons and economic interdependence (Allison 2017: 187-286). From the perspective of Occam's razor, Allison's explanations are clearly inferior to an explanation based on the strategic structure of hegemonic contest.
} 
of chicken, especially when both players escalate, but they lie in human errors, machinery defects, or other non-structural factors, not in Thucydides' Trap.

\section{Are We Entering a New Cold War?}

One powerful way to imagine the coming hegemonic contest is to compare it with the last - the Cold War. This question is not just an intellectual exercise, but it has a practical purpose. If the current great power competition is a new Cold War, then we can mine the Cold War for good strategies and good lessons. But if it is not, then we would rather find wisdom elsewhere. So, are we entering a new Cold War? The truth is mixed. The hegemonic contest between China and the United States is similar to the Cold War in some aspects, but it differs from the Cold War in many others.

The key similarity between the US-PRC competition and the US-USSR rivalry is that both are structured as games of chicken. This is because for both the United States and the PCR, like the United States and the Soviet Union during the Cold War, an all-out nuclear war is worse than their acceptance of the other's supremacy. Both the PRC and the United States are nuclear-armed to the extent that their weapons arsenals are enough to destroy both of them many times over. Each possesses the capability to strike back after being first hit by the other. And, most importantly, their political elites are well aware of this "overkill” effect of nuclear weapons (Kristensen and Koda 2019; Pearce and Denkenberger 2018; Fravel and Medeiros 2010; Xu 2016:24). Moreover, all the major powers involved in this strategic competition - the United States, China and Russia at the global level, and China, Russia, the United States, India, and Japan at the regional level in the Indo-Pacific - are all nuclear-armed, or, in the case of Japan, is under the nuclear umbrella of the United States. According to the logic of the chicken game, World War III is unlikely to occur, although high tensions and dangerous crises will abound and localized, conventional conflicts are possible.

With regard to strategy, if one side escalates and the other side deescalates, the more aggressive side will gain and the gains tend to be frozen into the status quo. But if both sides escalate, they will eventually reach some sort of agreement, expressly or tacitly. Knit together, 
these agreements will form a division of power between the main contenders, creating their spheres of influence in the major domains of contest.

Interactions in the East China Sea, the South China Sea, and along the Sino-Indian land border in the past decades followed neatly these patterns. China seized the Scarborough Shoal in 2012 after the Philippines, brokered by the United States, agreed to withdraw its Navy vessel from the scene (Heydarian 2015). During 2013-2017, China built several artificial islands in the disputed Spratly and Paracel Islands without any kinetic opposition by others. These are now parts of the "new normal" in the South China Sea (Beech 2018). By contrast, China's unilateral deployment of a giant oil rig, the HYSY-981, in waters claimed by Vietnam near the Paracels was met with vehement resistance from the latter, which held the line throughout the standoff by not only sending its law enforcement vessels to challenge Chinese ships on the ground, but also bringing the matter to international forums and international journalists to the scene. In the end, China had to withdraw its oil rig and tension was defused while China-Vietnam relations plummeted to the lowest point since 1988 (Vuving 2014a). In 2017 as well as 2020, China's attempt to change the status quo of the Sino-Indian border in the Doklam Plateau and Ladakh, respectively, was halted after India upped the ante (Myers, Barry and Fisher 2017; Hernandez 2017; Hutcheon, Doman and Palmer 2020).

Different perceptions about the propensity of the US-China strategic competition lead to different implications for strategy. If war is a structural tendency, as Allison in the United States and Hugh White in Australia believe, then in order to avert the worse, America, the ruling power, must be ready to share power with China, the rising power (Allison 2017; White 2013). This will turn a symmetric prisoner's dilemma into an asymmetric game in which China can still be aggressive but the United States will play chicken. The new structure eliminates the structural cause of war, but it also creates a structural tendency for Chinese hegemony and US acceptance of Chinese dominance. If the US-PRC rivalry is a symmetric game of chicken, US de-escalation in front to Chinese escalation and, at the macro level, US offer to share power with China in response to China's rising power or assertiveness remain a sensible strategy for one of the game's three Nash equilibria-but the worst of the three for America. A better strategy that can prevent both war and Chinese dominance is holding the line when China is testing your resolve and matching its escalation with your own while maintaining a channel for talks. 
The PRC's actions since its birth in 1949 indicate that China is a master player of the game of chicken. Beijing plays the 'aggressive but not very aggressive' actor, which cautious commentators call 'assertive'. As a true inheritor of Sun-tzu, who is famous for dictums such as 'all warfare is based on deception' and 'the supreme art of war is to subdue the enemy without fighting', China pursues psychological campaigns to disarm the mind of its opponents, making them think de-escalation is the best way to respond (Vuving 2019). When its opponent deescalates, China continues to escalate but just a few steps further than its opponent in order to reap strategic gains, then it stops short of open conflict. Its primary use of gray zone tactics is proof that China has full intent to keep the conflict below the threshold of an open military clash (Vuving 2017).

Gray zone approaches play on the gap between the fluid nature of reality and the rigid character of rules, norms, and conventions. Salami slicing, a tactic that flourished during the Cold War, was a chief source of success for China in the South China Sea and the Sino-Indian border. Another gray zone tactic - surrounding a target like a cabbage wrapping itself with layers of nonmilitary forces on the front and paramilitary forces in the middle, supported by military forces over the horizon - has helped China to seize Scarborough Shoal and enlarge its dominance in the South China Sea. Leveraging the third dimension of the gray zone-creating a fait accompli by stealth or surprise-also has a high success rate in the South China Sea. Based on the principles of deniability, camouflage, stealth, indirection, gradualism, and fait accompli, these tactics and others that will be invented or reinvented will gain strategic importance in the coming decades.

As kinetic war becomes too risky in the nuclear age, war by other means, such as economic warfare, information warfare, psychological warfare, 'lawfare' (the use of law as a weapon of conflict), and the weaponization of the non-military will be critical to future power competition (Blackwill and Harris 2016; Qiao and Wang 1999; Vuving 2019). An effective tactic in the game of chicken is 'riskfare' and China has been adept at this tactic in the East and South China Seas (Odom 2019). Riskfare is the deliberate use of risks that plays on the opponent's fear of escalation. As the fear of escalation tends to spread more freely and more quickly in open societies and smaller countries, China has a strong edge in weaponizing risks to achieve its objectives without the use of kinetic force.

The learning curves of other countries, especially the United States, Japan, India, and Australia, will be longer than China's to various extents, but they are also learning - everybody is 
learning. Due partly to this long learning process, but also to the nature of great power competition, the struggle over leadership in Asia and the world that broke to the surface in the 2010s will likely last for several decades. At the end of this decades-long competition, the final victor is likely the anti-China coalition led by the United States, India, and Japan. This coalition has more chance to win in the end because in its combination it is better positioned and better resourced than China.

Had China confined its hegemonic ambitions to Asia only and accepted US global primacy, the United States would have conceded supremacy in Asia to China, similar to the UK concession to US hegemony in the Western Hemisphere a century earlier. But China has already and aggressively challenged US power around the globe, not least with its extensive Belt and Road Initiative and its combative 5G domination campaign. That has brought home to the United States the China threat, raising the costs of US subordination to China globally, and rendering war the only force that can stop escalation.

The coming hegemonic contest between China and the United States will not resemble the Cold War much beyond its strategic structure. There will be an ideological conflict, with Washington and Beijing each promoting a different sets of values and principles of governance. As a Leninist regime, the PRC has never ceased to regard the 'capitalist-imperialist' America as its ideological enemy. The Trump administration has started a counteroffensive on the ideological front (O'Brien 2020). But the PRC's official ideology of 'socialism with Chinese characteristics' is unlikely to be an effective rallying cry in the international arena, while Beijing lacks an attractive ideology that champions universal, as opposed to nationalistic, values. To expand its soft power, China can rely not so much on the appeal of some universal values or the commitment to a shared ideology but primarily on the ethnic allegiance of the Chinese diaspora, guanxi with foreign partners, the attraction of the Chinese model, and the solidarity of those who share feelings of antiAmericanism.

Like the Soviet state, the PRC state also occupies the 'commanding heights of the economy'. But unlike the Soviet bloc, which was an autarky, China today trades extensively with the outside world and penetrates the world economy like no other states. By 2010, China overtook the United States as the larger trading partner of most countries in the world, including major US allies like South Korea, Australia, and Japan (Leng and Rajah 2019). Efforts to decouple from the 
Chinese market, if successful, will not result in two independent economic blocs as in the Cold War, but in two interconnected economic blocs that have little to no precedent in history.

The biggest difference between the current great power competition and the Cold War is related to the central domain of contest. During the Cold War, it was Europe because of the industrial capacity of the region and its proximity to the industrial core areas of the Soviet Union. For similar reasons, the great power competition of today is taking place most intensely in East and South Asia and in a new domain that did not exist in the Cold War-the cyber sphere. Most consequently for the stability of the contest, a key difference between the two peak periods of great power competition concerns the places of their main frontlines. The main frontlines of the Cold War were in the land domain and cut across Central Europe. It was relatively stable throughout the conflict because generally defense has the advantage over offense on land. Today, the main frontlines of hegemonic contest are in the maritime domain of the Western Pacific, cutting across the East and South China Seas and running through the Taiwan Strait, and in the cyber domain, cutting across individual countries. The East Asian seas are home to the lifeline of Asia, while the Internet is increasingly a critical lifeline of the world. Major efforts by the hegemonic contenders in these areas are to maintain and enlarge their own sphere of influence while trying to roll back and destroy that of the opponent.

The struggle for spheres of influence has no start and no end. In the East Asian seas, American advantage, gained after World War II, has gradually been eroded, in the manner of the salami slicing and the fait accompli, by China's stealthy occupation of the eastern part of the Paracel Islands in 1956, China's seizure of the western group of the islands from South Vietnam in 1974, China's occupation of six reefs in the Spratly Islands in 1988, China's stealthy occupation of Mischief Reef in 1995, China's “cabbage” seizure of Scarborough Shoal in 2012, and China's building of large artificial islands in the Paracel and Spratly Islands during 2013-2017 (Vuving 2014b). The disputed land border between China and India in the Himalayas also takes center stage in the contemporary great power competition. But because generally defense has the advantage on land while offense has the advantage in the sea, we will see, as we have seen in the last decade, more dramatic changes in the East Asian seas than on the Sino-Indian land border.

In the cyber domain, the Great Fire Wall of China has not only protected the regime from unfavorable ideas, but it has also helped to turn China into a great incubator for the country's 
leading tech companies to become world giants. When they go global, as they have since the early 2010s, they help expand the Chinese sphere of influence far beyond the border of China. In September 2018, former Google CEO Eric Schmidt predicted that 'the most likely scenario now is not a splintering, but rather a bifurcation into a Chinese-led internet and a non-Chinese internet led by America' (Kolodny 2018). Today, the division of the cyber domain into a Chinese sphere of influence and a US sphere of influence is well underway, with Huawei, the world's largest producer of $5 \mathrm{G}$ equipment, leading the effort to enlarge the Chinese sphere of influence. Like the British East India Company, Huawei is a private company that expands the power of its sovereign by conquering vast and critical areas, this time in the physical backbone of the cyber domain.

Non-existent before the 1990s, the cyber domain is virtual but not non-physical because it has a physical layer. Spheres of influence in this physical layer often reflects and reinforces those in the land domain. Once established, they are also far harder to change than spheres of influence in the maritime domain and the virtual space of the cyber domain. In all these domains, the logic of the game of chicken will apply: if you deescalate, your opponent will get a strong incentive to escalate and the more aggressive player will gain; but if both escalate, both will reach an agreement at the very end. Gray zone operations and hybrid warfare will be the critical instruments in this game of chicken.

\section{Conclusion}

One of the strategic objectives of Australia's 2020 Defence Strategic Update is to shape the country's strategic environment (Australian Government, Department of Defence 2020). Successive US National Security Strategies, at least from the Clinton to the Trump administration, also specify shaping the international environment to protect American interests and advance American values as an overarching foreign policy goal (White House 1998; White House 2017). How can one shape one's geopolitical environment effectively? Effective shaping of the environment is not the same as causing changes or making differences. Much of the time, it is like swimming efficiently in a river.

The river that is the strategic environment has numerous currents residing at different depths and moving at different speeds. These currents, some of which result from the effort to 
shape the strategic environment by various actors, create vortices large and small in the river. The hegemonic contest between China and the United States is forming the largest vortex in the strategic environment of the decades to come. Given its strategic position as a hinge country between the Indian and Pacific Oceans, Australia will be drawn into this vortex, with or without the US-Australia alliance. It is important for any player in this environment to recognize the strategic structure of the US-PRC hegemonic contest and apply the best strategy for it as suggested by this structure.

\section{Disclaimer}

The views expressed in this chapter are the author's own and do not reflect the official policy or position of the US government, the US Department of Defense, or DKI APCSS.

\section{References}

Al Jazeera (2020), 'Philippines Backs Vietnam after China Sinks Fishing Boat', 8 April, https://www.aljazeera.com/news/2020/04/philippines-backs-vietnam-china-sinks-fishing-boat200409022328432.html accessed 23 July 2020.

Allison, Graham (2017), Destined for War: Can America and China Escape Thucydides's Trap? Boston: Houghton Mifflin Hartcourt.

Asia Maritime Transparency Initiative (2020), 'Update: Chinese Survey Ship Escalates ThreeWay Standoff', May 18, https://amti.csis.org/chinese-survey-ship-escalates-three-way-standoff/ accessed 23 July 2020.

Australian Government Department of Defence (2020), 2020 Defence Strategic Update and 2020 Force Structure Plan, https://www.defence.gov.au/strategicupdate-2020/ accessed 23 July 2020.

Basu, Nayanima (2020), 'Pompeo Cites Ladakh Tensions, Accuses China of Playing 'Rogue Actor' Around the Word', The Print, 20 June, https://theprint.in/diplomacy/pompeo-cites- 
ladakh-tensions-accuses-china-of-playing-rogue-actor-around-world/445643/ accessed 23 July 2020.

Beech, Hannah (2018), 'China's Sea Control Is a Done Deal, "Short of War with the US”, The New York Times, September 20. https://www.nytimes.com/2018/09/20/world/asia/south-chinasea-navy.html accessed 23 July 2020.

Blackwill, Robert D. and Jennifer M. Harris (2016), War by Other Means: Geoeconomics and Statecraft, Cambridge, MA: Harvard University Press.

Bloomberg (2020), 'Japan to Fund Firms to Shift Production Out of China', The Economic Times, April 8, https://auto.economictimes.indiatimes.com/news/industry/japan-to-fund-firms-toshift-production-out-of-china/75053048 accessed 23 July 2020.

Colman, Andrew M. (2017), Game Theory and Its Applications: In the Social and Biological Sciences, New York: Routledge.

Fravel, M. Taylor and Evan S. Medeiros (2010), 'China's Search for Assured Retaliation', International Security, 35(2).

Goldstein, Joshua S. (1988), Long Cycles: Prosperity and War in the Modern Age, New Haven: Yale University Press.

Hernandez, Javier C. (2017), 'China and India Agree to Ease Tensions in Border Dispute', The New York Times, August 28, https://www.nytimes.com/2017/08/28/world/asia/china-indiastandoff-withdrawal.html accessed 23 July 2020.

Heydarian, Richard Javad (2015), Asia's New Battlefield: The USA, China, and the Struggle for the Western Pacific, London: Zed Books.

Hutcheon, Stephen, Mark Doman and Alex Palmer (2020), 'High Stakes in a Himalayan Hotspot', ABC News, 9 July, https://www.abc.net.au/news/2020-07-10/high-stakes-in-chinaindia-himalayan-border-hotspot/12417248?nw=0 accessed 23 July 2020.

Japan Times (2020), 'China to Conduct Major Military Drill Simulating Seizure of Taiwan-Held Island', May 14, https://www.japantimes.co.jp/news/2020/05/14/asia-pacific/china-military-drilltaiwan/ accessed 23 July 2020. 
Kolodny, Lora (2018), 'Former Google CEO Predicts the Internet Will Split in Two - And One Part Will Be Led by China', CNBC, September 20, https://www.cnbc.com/2018/09/20/ericschmidt-ex-google-ceo-predicts-internet-split-china.html accessed 23 July 2020.

Kristensen, Hans M. and Matt Koda (2019), 'Chinese Nuclear Forces, 2019,' Bulletin of the Atomic Scientists, 75(4).

Leng, Alyssa, Roland Rajah (2019), 'Chart of the Week: Global Trade Through a US-China Lens', The Interpreter, Lowy Institute, 18 December, https://www.lowyinstitute.org/theinterpreter/chart-week-global-trade-through-us-china-lens accessed 23 July 2020.

Medcalf, Rory (2020), Contest for the Indo-Pacific: Why China Won't Map the Future, La Trobe University Press.

Myers, Steven Lee, Ellen Barry, Max Fisher (2017), 'How India and China Have Come to the Brink Over a Remote Mountain Pass', The New York Times, July 26, https://www.nytimes.com/2017/07/26/world/asia/dolam-plateau-china-india-bhutan.html accessed 23 July 2020.

NASA (n.d.), 'Arctic Sea Ice Minimum' and 'Ice Sheets', Global Climate Change, Vital Signs of the Planet, https://climate.nasa.gov/vital-signs/arctic-sea-ice/ and https://climate.nasa.gov/vitalsigns/ice-sheets/ accessed 21 July 2020.

Nield, David (2018), 'This Pacific Island Was Expected to Disappear, But It's Actually Growing Larger', Science Alert, 15 February, https://www.sciencealert.com/pacific-island-nationexpected-to-sink-is-getting-bigger accessed 23 July 2020.

O’Brien, Robert C. (2020), 'The Chinese Communist Party's Ideology and Global Ambitions', remarks delivered by National Security Advisor Robert C. O’Brien on June 24, 2020, in Phoenix, Arizona, https://www.whitehouse.gov/briefings-statements/chinese-communist-partys-ideologyglobal-ambitions/ accessed 23 July 2020.

Odom, Jonathan G. (2019), 'China's “Riskfare”, , Proceedings, United States Naval Institute, Vol. 145, No. 3 (March).

Pamuk, Humeyra and Andrea Shalal (2020), 'Trump Administration Pushing to Rip Global Supply Chains from China: Officials', Reuters, May 3, https://www.reuters.com/article/us- 
health-coronavirus-usa-china/trump-administration-pushing-to-rip-global-supply-chains-fromchina-officials-idUSKBN22G0BZ accessed 23 July 2020.

Pearce, Joshua M. and David C. Denkenberger (2018), ‘A National Pragmatic Safety Limit for Nuclear Weapon Quantities', Safety, 4(2).

Pompeo, Michael R. (2020a), 'Secretary Michael R. Pompeo at a Press Availability', Remarks to the Press, Washington DC, April 29, https://www.state.gov/secretary-michael-r-pompeo-at-apress-availability-4/ accessed 23 July 2020.

Pompeo, Michael R. (2020b), 'U.S. Position on Maritime Claims in the South China Sea', Press Statement of the Secretary of State, July 13, https://www.state.gov/u-s-position-on-maritimeclaims-in-the-south-china-sea/ accessed 23 July 2020.

PTI (2020), 'Pompeo Extends Deepest Condolences to Indians for Loss of Soldiers' Lives in Clashes with Chinese', Times of India, June 19, https://timesofindia.indiatimes.com/india/pompeo-extends-deepest-condolences-to-indians-forloss-of-soldiers-lives-in-clashes-with-chinese/articleshow/76456099.cms accessed 23 July 2020.

Qiao Liang and Wang Xiangsui (1999), Unrestricted Warfare (Beijing: PLA Literature and Arts Publishing House), translated by FBIS, https://www.c4i.org/unrestricted.pdf accessed 23 July 2020.

Sun Tzu (1963), Art of War, trans. Samuel B. Griffith, New York: Oxford University Press. Thucydides $\left(5^{\text {th }}\right.$ century BC), The History of the Peloponnesian War, translated by Richard Crawley, https://www.gutenberg.org/files/7142/7142-h/7142-h.htm accessed 23 July 2020.

Trevithick, Joseph (2020), 'Here Are Photos of Two U.S. Navy Carriers in the South China Sea for the First Time in Six Years', The War Zone, July 6, https://www.thedrive.com/the-warzone/34598/here-are-photos-of-two-u-s-navy-carriers-in-the-south-china-sea-for-first-time-insix-years accessed 23 July 2020.

United Nations, Department of Economic and Social Affairs, Population Division (2019), World Population Prospects 2019, Vol. II: Demographic Profiles, https://population.un.org/wpp/Publications/ accessed 23 July 2020. 
Vuving, Alexander L. (2014a), 'Did China Blink in the South China Sea?' The National Interest, July 27, https://nationalinterest.org/feature/did-china-blink-the-south-china-sea-10956 accessed 23 July 2020.

Vuving, Alexander L. (2014b), 'China's Grand Strategy Challenge: Creating Its Own Islands in the South China Sea', The National Interest, December 8, https://nationalinterest.org/feature/chinas-grand-strategy-challenge-creating-its-own-islands-the$\underline{11807}$ accessed 23 July 2020.

Vuving, Alexander L. (2017), 'How America Can Take Control in the South China Sea', Foreign Policy, February 13, https://foreignpolicy.com/2017/02/13/how-the-u-s-can-takecontrol-in-the-south-china-sea/ accessed 23 July 2020.

Vuving, Alexander L. (2019), 'China’s Strategic Messaging: What It Is, How It Works, and How to Respond to it,' in McDonald, Scott D. and Michael C. Burgoyne (eds.), China's Global Influence: Perspectives and Recommendations, Honolulu: Daniel K. Inouye Asia-Pacific Center for Security Studies, https://apcss.org/wp-content/uploads/2019/09/10-

Chinas_strategic_messaging-vuving.pdf accessed 23 July 2020.

Vuving, Alexander L. (2020), 'Great Power Competition: Lessons from the Past, Implications for the Future', in Vuving, Alexander L. (ed.), Hindsight, Insight, Foresight: Thinking about Security in the Indo-Pacific, Honolulu: Daniel K. Inouye Asia-Pacific Center for Security Studies.

White, Hugh (2013), The China Choice: Why We Should Share Power, Oxford: Oxford University Press.

White House, The (1998), A National Security Strategy for a New Century, October, https://www.hsdl.org/?view\&did=2959 accessed 23 July 2020.

White House, The (2017), National Security Strategy of the United States of America, December, https://www.whitehouse.gov/wp-content/uploads/2017/12/NSS-Final-12-18-2017-0905.pdf accessed 23 July 2020. 
Xu Weidi (2016), 'China's Security Environment and the Role of Nuclear Weapons', in Li Bin and Tong Zhao (eds.), Understanding Chinese Nuclear Thinking, Washington, DC: Carnegie Endowment for International Peace.

\section{Strategy and Outcome of Great Power Competition}

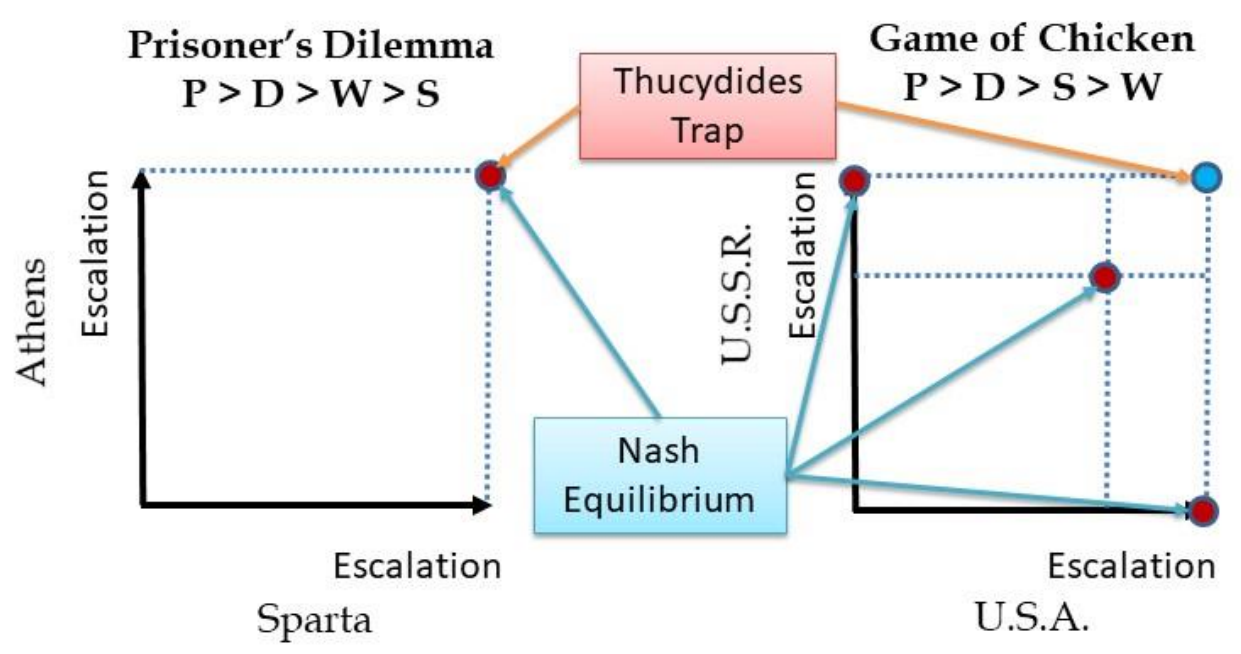

Figure 1. Strategy and Outcome of Great Power Competition. 